Penerbit:

Program Studi Magister Ilmu Kesehatan Masyarakat, Program Pascasarjana, Universitas Sam Ratulangi

Indonesian Journal of Public Health and Community Medicine is indexed by Google Scholar and licensed under a Creative Commons Attribution 4.0 International License.

\title{
Faktor-faktor Marketing Mix yang Berhubungan dengan Keputusan Pasien Memilih Rawat Inap Rumah Sakit Manembo-Nembo Bitung
}

\author{
Rickhard W. Makawimbang ${ }^{1 *}$, Grace E. C. Korompis ${ }^{2}$, dan Silvya L. Mandey ${ }^{3}$ \\ 1. Program Studi Ilmu Kesehatan Masyarakat, Program Pascasarjana Universitas \\ Sam Ratulangi \\ 2. Fakultas Kedokteran Universitas Sam Ratulangi \\ 3. Fakultas Kesehatan Masyarakat Universitas Sam Ratulangi \\ *E-mail: rwmakawimbang@yahoo.com
}

\begin{abstract}
Abstrak
Latar Belakang: Manajemen pemasaran rumah sakit merupakan upaya yang dapat dilakukan agar utilisasi pelayanan rumah sakit menjadi lebih tinggi sehingga berdampak terhadap keputusan pasien memilih rumah sakit, tinggi rendahnya keinginan konsumen atau masyarakat memakai suatu produk jasa pada rumah sakit berdasarkan penerapan marketing mix yang ada. Metode Penelitian: Penelitian ini termasuk studi observasional dengan rancangan penelitian cross sectional study. Populasi dalam penelitian ini adalah pasien dari seluruh kelas perawatan di Rumah Sakit. Sampel dalam penelitian adalah sampel yang memenuhi kriteria inklusi dan eksklusi yang berjumlah 53 pasien. Variabel dalam penelitian ini yaitu variabel marketing mix yaitu: lokasi, biaya, personil, promosi, bukti fisik, produk dengan variabel dependen yaitu keputusan memilih rawat inap. Data hasil penelitian dianalisis secara univariat, bivariat dan multivariat dan perhitungan statisik regresi logistik. Penyajian data dibuat dalam bentuk tabel dan narasi. Hasil Penelitian: Hasil penelitian yang menunjukan bahwa terdapat hubungan yang bermakna antara lokasi dengan keputusan memilih rawat inap dengan nilai $p=0,004$, terdapat hubungan yang bermakna antara biaya dengan keputusan memilih rawat inap dengan nilai $p=$ 0,000 , terdapat hubungan yang bermakna antara personil dengan keputusan memilih rawat inap dengan nilai $p=0,000$, tidak terdapat hubungan yang bermakna antara promosi dengan keputusan memilih rawat inap dengan nilai $p=0,184$, terdapat hubungan yang bermakna antara proses dengan keputusan memilih rawat inap dengan nila $p=0,018$, terdapat hubungan antara produk dengan keputusan memilih rawat inap dengan nilai $p=0,013$ dan tidak terdapat hubungan yang bermakna antara bukti fisik dengan keputusan memilih rawat inap dengan nilai $p=0,300$. Hasil analisis secara multivariat menunjukan bahwa biaya $(p=0,001)$ merupakan faktor yang paling dominan berpengaruh terhadap keputusan memilih rawat inap di Rumah Sakit Manembo-nembo Tipe C Bitung. Kesimpulan: Kesimpulan penelitian ini yaitu factor lokasi, biaya, personil, proses dan produk berhubungan dengan keputusan memilih rawat inap. faktor yang paling dominan yang berhubungan dengan keputusan memilih rawat inap adalah biaya.
\end{abstract}

Kata Kunci: Marketing Mix; Pasien Rawat Inap; Keputusan memilih rawat inap 


\begin{abstract}
Background: Hospital marketing management is an effort that can be done to make utilization of hospital services higher and thus impact on the decision of patient choosing a hospital, the high and low desire of consumers or the public to use a hospital service product based on the application of the existing marketing mix. Research Methods: This study was an observational study with a cross sectional study design. The population in this study were patients from all classes of hospital care. The sample in the study was a sample that met the inclusion and exclusion criteria of 53 patients. The variables in this study were the marketing mix variable, namely: location, cost, personnel, promotion, physical evidence, products with the dependent variable, namely the decision to choose hospitalization. The research data were analyzed using univariate, bivariate and multivariate analysis and logistic regression statistical calculations. Presentation of data was made in table and narrative form. The research data were analyzed using univariate, bivariate and multivariate analysis and logistic regression statistical calculations. Data presentation was made in the form of tables and narratives. Research Results: The results showed that there was a significant relationship between the location and the decision to choose hospitalization with a value of $\mathrm{p}=0.004$, there was a significant relationship between costs and the decision to choose hospitalization with a value of $\mathrm{p}=0.000$, there was a significant relationship between personnel and the decision to choose hospitalization with a value of $\mathrm{p}=$ 0,000 , there was no significant relationship between promotion and the decision to choose hospitalization with a value of $p=0.184$, there was a significant relationship between the process and the decision to choose hospitalization with a value of $p=0.018$, there was a relationship between the product and the decision choosing hospitalization with a value of $p=0.013$ and there was no significant relationship between physical evidence and the decision to choose to be hospitalized with a value of $\mathrm{p}=0.300$. The results of the multivariate analysis showed that cost ( $p=0.001)$ was the most dominant factor influencing the decision to choose to be hospitalized at Manembo-nembo Type C Hospital. Conclusion: The conclusion of this study is that the factors of location, cost, personnel, processes and products are related to the decision to choose to be hospitalized. The most dominant factor related to the decision to choose to hospitalization is cost.
\end{abstract}

Key words: Marketing Mix; Inpatients; The decision to choose hospitalization

\title{
PENDAHULUAN
}

Manajemen pemasaran rumah sakit merupakan upaya yang dapat dilakukan agar utilisasi pelayanan rumah sakit menjadi lebih tinggi sehingga berdampak pada meningkatnya derajat kesehatan masyarakat. Tujuan pemasaran rumah sakit adalah memperkenalkan rumah sakit pada masyarakt luas, menginformasikan sejelas-jelasnya mengenai fasilitas dan kemampuan pelayanan yang dimiliki oleh rumah sakit (Saragih dkk, 2017).

Bauran pemasaran atau marketing mix adalah kombinasi dari empat atau lebih variabel atau kegiatan yang merupakan ini dari sistem pemasaran perusahaan (Rinaldi, 2018). Peran pemasaran di rumah sakit sangat penting yaitu untuk memperkenalkan suatu produk yang ada di rumah sakit kepada seluruh pengguna jasa layanan. Para pengguna jasa layanan memiliki hak untuk memilih apa yang diinginkannya, dilihat dari berbagai kebutuhan dari pengguna jasa layanan tersebut dengan adanya pemasaran maka para pengguna jasa layanan bisa lebih mengetahui produk apa saja yang tersedia di suatu rumah sakit.

Marketing mix ternyata memiliki peranan penting terhadap keputusan pasien memilih rumah sakit. Tinggi rendahnya keinginan konsumen atau masyarakat memakai suatu produk jasa pada rumah sakit berdasarkan penerapan marketing mix yang ada. Bagaimanapun berkualitasnya suatu produk, harga maupun tempat yang ada pada rumah 
sakit jika penyampaian informasi pada masyarakat masih kurang informatif tentu akan berpengaruh terhadap keputusan pasien memilih rumah sakit karena kurangnya informasi yang didapatkan (Sabran dkk, 2014).

Sebagai sebuah organisasi yang menghasilkan produk jasa kesehatan, salah satu faktor yang menentukan mutu produk adalah personil pelaksana yang penuh dedikasi. Ini akan tercapai bila pengelola mampu menimbulkan rasa bangga pada karyawan tentang pekerjaannya dan keterlibatan semua karyawan secara aktif. Ini merupakan serangkaian variabel pemasaran yang dapat dikendalikan dan dipakai oleh pelaksana pemasaran rumah sakit untuk memasarkan jasa kesehatan yang dihasilkan (Aditama, 2010). Di Indonesia rumah sakit sebagai salah satu bagian sistem pelayanan kesehatan secara garis besar memberikan pelayanan untuk masyarakat berupa pelayanan kesehatan untuk masyarakat berupa pelayanan kesehatan yang mencakup pelayanan medik, pelayanan penunjang medik, rehabilitasi medik dan pelayanan perawatan. Pelayanan tersebut dilaksanakan melalui unit gawat darurat, unit rawat jalan dan unit rawat inap (Herlambang, 2016).

Penelitian yang dilakukan Tumiwa (2016) di Rumah Sakit Umum Pancaran Kasih GMIM Manado tentang Hubungan antara Bauran Pemasaran dan Pekerjaan dengan Keputusan Pasien Memilih Rawat Inap mendapatkan hasil terdapat hubungan yang signifikan antara harga, lokasi dan pekerjaan dengan keputusan pasien mamilih rawat inap, sedangkan produk dan promosi tidak memiliki hubungan yang signifikan dengan keputusan untuk ememilih rawat inap. Retnaningtyas (2016) dalam penelitiannya tentang Persepsi Pasien terhadap Bauran Pemasaran Rumah Sakit dan Pilihan Rumah Sakit mendapatkan hasil yang menunjukan persepsi positif pada bauran produk, proses, tariff dan keahlian namun pada aspek lokasi, promosi serta penampilan fisik dianggap kurang. Penelitian yang dilakukan Rawung (2013) di Rumah Sakit Jiwa Prof. Dr. V. L. Ratumbuysang mendapatkan hasil bauran pemasaran produk, petugas, proses dan bukti fisik memiliki hubungan yang signifikansi dengan loyalitas pasien, sedangkan bauran pemasaran harga, tempat dan promosi tidak memiliki hubungan yang signifikan dengan loyalitas pasien. Rengkuan (2015) menganalisis tentang hubungan antara persepsi pasien umum tentang bauran pemasaran jasa dnegan loyalitas pasien di RS Advent Manado, mendapatkan hasil yang menunjukkan bahwa ada hubungan antara bauran pemasaran jasa produk, harga, tempat dan bukti fisik dengan loyalitas pasien sedangkan bauran jasa petugas, promosi tidak ada hubungan yang signifikan.

Potensi rumah sakit merupakan seluruh sumber yang dimiliki termasuk semua sumber daya rumah sakit sebagai input, manajemen sebagai proses dan produk pelayanan kesehatan sebagai hasilnya dan diharapkan rumah sakit bisa menjual produk yang dihasilkan tersebut. Dalam rangka tetap menjaga produk rumah sakit tersebut dapat bersaing, maka produk tersebut selain bermutu juga harus sesuai dengan kriteria kebutuhan masyarakat. Dalam menentukan konsumen sasaran, rumah sakit perlu memahami perilaku konsumen dalam proses pengambilan keputusan.

Di Kota Bitung, terdapat 3 (tiga) Rumah Sakit yang menawarkan jasa layan kesehatan, 2 (dua) diantaranya adalah Rumah Sakit Swasta dengan jaminan pelayanan yang sama dengan UPTD Rumah Sakit Manembo-Nembo Tipe C Bitung. Sebagai satusatunya Rumah Sakit Pemerintah yang ada di Kota Bitung dengan adanya kondisi ini menimbulkan adanya persaingan rumah sakit swasta dan ruma sakit pemerintah sehingga rumah sakit harus mempertahankan Customer (pasien) dan merebut Customer pesaing. Pada dasarnya rumah sakit yang tidak melakukan inovasi dan inovasi-inovasi baru dan tidak meningkatkan mutu pelayanan akan ditinggalkan masyarakat pengguna jasa, 
sedangkan rumah sakit yang mengutamakan kepuasan dan kepentingan pasien akan memperoleh manfaat dan pegawai yang termotivasi. Pada akhirnya pasien yang menentukan mutu pelayanan jasa tersebut dan bukan rumah sakit, yang dapat dilihat dari keputusan pasien untuk kembali menggunakan layanan jasa kesehatan yang ditawarkan sebuah rumah sakit.

UPTD Rumah Sakit Manembo-Nembo Tipe C Bitung, tidak memiliki unit pemasaran Rumah sakit, hal ini dapat berdampak pada kurangnya informasi tentang jasa layanan yang ditawarkan rumah sakit kepada pasien (pelanggan), hal ini dapat dilihat dari data awal yang diperoleh di bagian rekam medik diketahui bahwa jumlah kunjungan pasien rawat inap UPTD Rumah Sakit Manembo-Nembo Tipe C Bitung dalam kurun waktu empat tahun terakhir dari tahun 2015 sampai tahun 2018 yang berada dalam keadaan yang berfluktuasi. Terdapat 2 jenis pembayaran asien yaitu: pasien dengan cara bayar umum, pasien dengan tanggungan asuransi: antara lain BPJS, Inhealth dan asura nsi lainnya. Data yang didapatkan bahwa hampir sebagian besar pasien yang dirawat inap adalah pasien dengan cara bayar ditanggung oleh BPJS Kesehatan yaitu sebanyak (90\%) dari total kunjungan. Sehingga (10\%) lainnya adalah pasien dengan cara bayar umum. Data kunjungan pasien rawat inap pada tahun 2015 sebanyak 8.361 pasien, 2016 sebanyak 8.969 pasien, pada tahun 2017 jumlah kunjungan pasien rawat inap sebanyak 8.326 pasien, dan pada tahun 2018 jumlah kunjungan pasien rawat inap sebanyak 9.976 pasien, sedangkan untuk tahun 2019 bulan januari sampai bulan juni jumlah kunjungan pasien rawat inap sebanyak 3.710 pasien dan sekitra $10 \%$ atau 371 adalah total kunjungan pasien umum.

Keadaan fluktuasi kunjungan pasien rawat inap di UPTD Rumah Sakit ManemboNembo Tipe C Bitung merupakan masalah yang tidak bisa dibiarkan begitu saja oleh pihak rumah sakit terutama bagian yang menangani pemasaran rumah sakit. Keputusan paling mendasar yang harus dibuat oleh pihak rumah sakit adalah perihal pelayanan yang akan ditawarkan yang didukung dengan mengetahui dan mengembangkan faktor-faktor marketing mix yang berhubungan dengan keputusan pasien untuk menggunakan jasa pelayanan di UPTD Rumah Sakit Manembo-Nembo Tipe C Bitung. Tujuan penelitian ini yaitu untuk hubungan antara persepsi pasien mengenai marketing mix dengan keputusan untuk memilih rawat inap di UPTD Rumah Sakit Manembo-Nembo Tipe C Bitung.

\section{METODE PENELITIAN}

Penelitian ini termasuk studi observasional dengan rancangan penelitian cross sectional study. Populasi dalam penelitian ini yaitu seluruh Pasien di UPTD Rumah Sakit Manembo-Nembo Tipe C Bitung. Populasi dalam penelitian ini adalah pasien dari seluruh kelas perawatan di Rumah Sakit. Sampel dalam penelitian adalah sampel yang memenuhi kriteria inklusi dan eksklusi yang berjumlah 53 pasien. Variabel dalam penelitian ini yaitu variabel marketing mix yaitu: lokasi, biaya, personil, promosi, bukti fisik, produk dengan variabel dependen yaitu keputusan memilih rawat inap. Data hasil penelitian dianalisis secara univariat, bivariat dan multivariat dan perhitungan statisik Regresi Logistik. Penyajian data dibuat dalam bentuk tabel dan narasi.

\section{HASIL DAN PEMBAHASAN}

\section{Analisis univariat}

Hasil penelitian untuk karakteristik responden dapat diketahui bahwa sebagian besar responden berusia kurang dari 25 tahun sebanyak 23 responden $(43,4 \%)$, diikuti umur diatas 46 tahun sebanyak 19 responden $(35,8 \%)$ dan rata-rata umur antara 25 sampai 
dengan 45 tahun sebanyak 11 responden $(20,8 \%)$. Karakteristik responden berdasarkan jenis kelamin yang diketahui dari tabel 2, dapat dijelaskan bahwa sebagian besar responden adalah laki-laki yaitu sebanyak 28 responden $(52,8 \%)$ dan perempuan sebanyak 25 responden $(47,2 \%)$. Tingkat pendidikan dalam penelitian terdiri dari 4 tingkat pendidikan yaitu: SMP, SMA, Diploma III dan Pendidikan Sarjana (S1) hasil penelitian dari tabel 2 menunjukkan bahwa tingkat pendidikan yang dominan adalah tingkat pendidikan Sekolah Menengah Atas (SMA) sebanyak 33 responden (32,3\%), diikuti tingkat pendidikan Diploma III sebanyak 11 responden $(20,8 \%)$ dan yang paling sedikit adalah tingkat pendidikan Sekolah Menengah Pertama (SMP) yaitu sebanyak 2 responden $(3,8 \%)$.

Distribusi pekerjaan responden terbagi atas 4 kategori pekerjaan yaitu: Tidak bekerja, nelayan, wiraswasta dan PNS. Hasil penelitian didapat pekerjaan responden yang paling banyak adalah wiraswasta sebanyak 25 responden $(11,3 \%)$, diikuti kategori tidak bekerja sebanyak 16 responden $(30,2 \%)$ dan yang paling sedikit adalah pekerjaan sebagai PNS dan Nelayan yaitu sebanyak 6 responden $(11,3 \%)$.

Tabel 1. Karakteristik Responden

\begin{tabular}{|c|c|c|}
\hline Karakteristik & $\mathrm{N}$ & $\%$ \\
\hline \multicolumn{3}{|l|}{ Umur } \\
\hline$<25$ tahun & 23 & 43.4 \\
\hline $25-45$ tahun & 11 & 20.8 \\
\hline$>46$ tahun & 19 & 35.8 \\
\hline Total & 53 & 100 \\
\hline \multicolumn{3}{|l|}{ Jenis Kelamin } \\
\hline Laki-laki & 28 & 52.8 \\
\hline Perempuan & 25 & 47.2 \\
\hline Total & 53 & 100 \\
\hline \multicolumn{3}{|l|}{ Tingkat Pendidikan } \\
\hline SMP & 2 & 3.8 \\
\hline SMA & 33 & 62.3 \\
\hline D-III & 11 & 20.8 \\
\hline S1 & 7 & 13.2 \\
\hline Total & 53 & 100 \\
\hline \multicolumn{3}{|l|}{ Pekerjaan } \\
\hline Tidak & 16 & 30.2 \\
\hline Nelayan & 6 & 11.3 \\
\hline Wiraswasta & 25 & 47.2 \\
\hline PNS & 6 & 11.3 \\
\hline Total & 53 & 100 \\
\hline
\end{tabular}

Data tabel 1 di atas dapat diketahui bahwa sebagian besar responden berusia kurang dari 25 tahun sebanyak 23 responden (43,4\%), diikuti umur diatas 46 tahun sebanyak 19 responden $(35,8 \%)$ dan rata-rata umur antara 25 sampai dengan 45 tahun sebanyak 11 responden $(20,8 \%)$.

Karakteristik responden berdasarkan jenis kelamin yang diketahui dari tabel 2, dapat dijelaskan bahwa sebagian besar responden adalah laki-laki yaitu sebanyak 28 responden $(52,8 \%)$ dan perempuan sebanyak 25 responden $(47,2 \%)$. Tingkat pendidikan dalam penelitian terdiri dari 4 tingkat pendidikan yaitu: SMP, SMA, Diploma III dan Pendidikan Sarjana (S1) hasil penelitian dari tabel 2 menunjukkan bahwa tingkat pendidikan yang dominan adalah tingkat pendidikan Sekolah Menengah Atas (SMA) 
sebanyak 33 responden (32,3\%), diikuti tingkat pendidikan Diploma III sebanyak 11 responden $(20,8 \%)$ dan yang paling sedikit adalah tingkat pendidikan Sekolah Menengah Pertama (SMP) yaitu sebanyak 2 responden $(3,8 \%)$.

Distribusi pekerjaan responden terbagi atas 4 kategori pekerjaan yaitu: Tidak bekerja, nelayan, wiraswasta dan PNS. Hasil penelitian didapat pekerjaan responden yang paling banyak adalah wiraswasta sebanyak 25 responden (11,3\%), diikuti kategori tidak bekerja sebanyak 16 responden $(30,2 \%)$ dan yang paling sedikit adalah pekerjaan sebagai PNS dan Nelayan yaitu sebanyak 6 responden $(11,3 \%)$.

Tabel 2. Tabel Distribusi Frekuensi Berdasarkan Lokasi, Biaya, Personil, Promosi, Fisik, Proses, Produk dan Keputusan.

\begin{tabular}{lcc}
\hline \multicolumn{1}{c}{ Kategori } & N=53 & \% \\
\hline Terjangkau & Lokasi & 52,8 \\
Kurang terjangkau & 28 & 47,2 \\
Terjangkau & 25 & \\
Kurang terjangkau & Biaya & 54,7 \\
& 29 & 45,3 \\
Baik & 24 & \\
Kurang baik & Personil & 67,9 \\
& 36 & 32,1 \\
Baik & 17 & 35,8 \\
Kurang baik & Promosi & 64,2 \\
& 19 & \\
Baik & 34 & 75,5 \\
Kurang baik & Fisik & 24,5 \\
& 40 & 79,2 \\
Baik & 13 & 20,8 \\
Kurang baik & Proses & 64,2 \\
Baik & 42 & 35,8 \\
Kurang baik & 11 & 50,9 \\
Loyal & Produk & 49,1 \\
Kurang Loyal & 34 & \\
\hline
\end{tabular}

Dari data tabel di atas dapat diketahui bahwa persepsi pasien terhadap Lokasi di Rumah Sakit pada kategori terjangkau 28 responden $(52,8 \%)$ dan kurang terjangkau sebanyak 25 responden (47,2\%). Dari hail ini menunjukan bahwa lokasi Rumah Sakit adalah terjangkau. Persepsi pasien terhadap biaya pelayanan di Rumah Sakit pada kategori terjangkau 29 responden $(54,7 \%)$ dan kurang terjangkau sebanyak 24 responden $(45,3 \%)$. Dari hal ini menunjukkan bahwa biaya Rumah Sakit adalah terjangkau.

Persepsi pasien terhadap personil pemberi pelayanan di Rumah Sakit pada kategori baik 36 responden $(67,9 \%)$ dan kurang baik sebanyak 17 responden $(32,1 \%)$. Dari hal ini menunjukkan bahwa sebagian besar personil pemberi pelayanan kesehatan di Rumah Sakit adalah baik. Persepsi pasien rawat inap terhadap promosi pelayanan Rumah 
Sakit pada kategori kurang baik 34 responden $(64,2 \%)$ dan baik sebanyak 19 responden $(35,8 \%)$. Dari hal ini menunjukkan bahwa sebagian besar kegiatan promosi layanan kesehatan di Rumah Sakit adalah kurang baik.

Dari tabel di atas dapat diketahui bahwa persepsi pasien rawat inap terhadap keadaan fisik Rumah Sakit pada kategori baik 40 responden $(75,5 \%)$ dan kurang baik sebanyak 13 responden $(24,5 \%)$. Dari hal ini menunjukkan bahwa sebagian besar keadaan fisik Rumah Sakit adalah baik. Persepsi pasien rawat inap terhadap proses pelayanan di Rumah Sakit pada kategori baik sebanyak 42 responden $(72,9 \%)$ dan kurang baik 11 responden $(20,8 \%)$. Dari hal ini menunjukkan bahwa sebagian besar proses pelayanan di Rumah Sakit adalah kurang baik.

Persepsi pasien rawat inap terhadap produk pelayanan Rumah Sakit pada kategori baik 34 responden $(64,2 \%)$ dan kurang baik sebanyak 19 responden $(35,8 \%)$. Dari hal ini menunjukkan bahwa sebagian besar produk pelayanan di Rumah Sakit adalah baik. Keputusan pasien rawat inap memilih untuk di rawat inap adalah pada kategori loyal 27 responden $(50,9 \%)$ dan kurang loyal sebanyak 26 responden $(49,1 \%)$. Dari hal ini menunjukkan bahwa keputusan pasien memilih rawat inap di RSUD Bitung adalah kurang loyal.

\section{Tabel 3. Analisis Bivariat}

\begin{tabular}{|c|c|c|c|c|c|c|c|}
\hline \multirow{3}{*}{ Kategori } & \multicolumn{6}{|c|}{ Keputusan memilih rawat inap } & \multirow[b]{3}{*}{$\mathbf{p}$} \\
\hline & \multicolumn{2}{|c|}{ Loyal } & \multicolumn{2}{|c|}{ Kurang loyal } & \multicolumn{2}{|c|}{ Total } & \\
\hline & $\mathrm{N}$ & $\%$ & $N$ & $\%$ & $\mathrm{~N}$ & $\%$ & \\
\hline \multicolumn{8}{|c|}{ Lokasi } \\
\hline Terjangkau & 19 & 35,8 & 9 & 17,0 & 28 & 52,8 & \multirow{3}{*}{$\begin{array}{c}\mathrm{p}=\mathrm{O}, \mathrm{004} \\
\mathrm{OR}=5,429\end{array}$} \\
\hline $\begin{array}{l}\text { Kurang } \\
\text { Terjangkau }\end{array}$ & 7 & 13,2 & 18 & 34,0 & 25 & 47,2 & \\
\hline Total & 26 & 49.1 & 27 & 50.9 & 53 & 100 & \\
\hline \multicolumn{8}{|c|}{ Biaya } \\
\hline Terjangkau & 21 & 39,6 & 8 & 15,1 & 29 & 54,7 & \multirow{3}{*}{$\begin{array}{c}\mathrm{p}=\mathrm{O}, \mathrm{OO0} \\
\mathrm{OR}=9,975\end{array}$} \\
\hline $\begin{array}{l}\text { Kurang } \\
\text { Terjangkau }\end{array}$ & 5 & 9,4 & 19 & 35,8 & 24 & 45,3 & \\
\hline Total & 26 & 49.1 & 27 & 50.9 & 53 & 100 & \\
\hline \multicolumn{8}{|c|}{ Personil } \\
\hline Baik & 21 & 39,6 & 15 & 25,3 & 36 & 67,9 & \multirow{3}{*}{$\begin{array}{c}\mathrm{p}=0,000 \\
\mathrm{OR}=3,360\end{array}$} \\
\hline Kurang baik & 5 & 9,4 & 12 & 22,6 & 17 & 32,1 & \\
\hline Total & 26 & 49.1 & 27 & 50.9 & 53 & 100 & \\
\hline \multicolumn{8}{|c|}{ Promosi } \\
\hline Baik & 7 & 13,2 & 12 & 22,6 & 19 & 35,8 & \multirow{3}{*}{$\begin{array}{c}\mathrm{p}=0,184 \\
\mathrm{OR}=0,461\end{array}$} \\
\hline Kurang baik & 19 & 35,8 & 15 & 28,3 & 34 & 64,2 & \\
\hline Total & 26 & 49.1 & 27 & 50.9 & 53 & 100 & \\
\hline \multicolumn{8}{|c|}{ Bukti Fisik } \\
\hline Baik & 18 & 34,0 & 22 & 41,5 & 40 & 75,5 & \multirow{3}{*}{$\begin{array}{c}\mathrm{p}=0,300 \\
\mathrm{OR}=0,511\end{array}$} \\
\hline Kurang baik & 8 & 15,1 & 5 & 9,4 & 13 & 24,5 & \\
\hline Total & 26 & 49.1 & 27 & 50.9 & 53 & 100 & \\
\hline \multicolumn{8}{|c|}{ Proses } \\
\hline Baik & 20 & 37,7 & 22 & 41,5 & 42 & 79,2 & \multirow{3}{*}{$\begin{array}{c}\mathrm{p}=0,018 \\
\mathrm{OR}=0,253\end{array}$} \\
\hline Kurang baik & 6 & 11,3 & 5 & 9,4 & 11 & 20,8 & \\
\hline Total & 26 & 49.1 & 27 & 50.9 & 53 & 100 & \\
\hline \multicolumn{8}{|c|}{ Produk } \\
\hline Baik & 21 & 39,6 & 13 & 24,5 & 31 & 64,2 & \multirow{3}{*}{$\begin{array}{c}\mathrm{p}=0,013 \\
\mathrm{OR}=4,523\end{array}$} \\
\hline Kurang baik & 5 & 9,4 & 14 & 26,4 & 19 & 35,8 & \\
\hline Total & 26 & 49.1 & 27 & 50.9 & 53 & 100 & \\
\hline
\end{tabular}


Pada Tabel 3, dapat dijelaskan hasil analisis lokasi dengan keputusan dalam hal ini loyalitas responden dalam menggunakan kembali fasilitas RS, diperoleh data jumlah responden menjawab terjangkau 28 responden (52,8\%) dengan loyal sebanyak 19 responden $(35,8 \%)$ dan kurang loyal sebanyak 9 responden $(17,0 \%)$; sedangkan responden yang menjawab kurang terjangkau 25 responden $(47,2 \%)$ dengan loyal sebanyak 7 responden $(13,2 \%)$ dan kurang loyal sebanyak 18 responden $(34,0 \%)$. Berdasarkan hasil uji analisis chi-square didapatkan hasil dengan nilai $\mathrm{p}=0,004<\mathrm{a}=0,05$ yang menunjukkan terdapat hubungan yang bermakna antara lokasi (place) dengan keputusan memilih rawat inap di UPTD Rumah Sakit Manembo-Nembo Tipe C Bitung. Nilai Odd lokasi dihitung dengan membandingkan lokasi kurang terjangkau (numerator) dan terjangkau (denominator) terhadap keputusan untuk tidak memilih rawat inap di RS (kurang loyal). Nilai Odd sebesar 5,429 berarti bahwa responden dengan lokasi yang kurang terjangkau berisiko untuk kurang loyal sebesar 5,429 atau 5 kali lebih besar berisiko untuk tidak memilih dirawat kembali (kurang loyal) dibandingan dengan responden yang menjawab lokasi terjangkau. Nilai kepercayaan diperoleh $(1,669)$ sampai dengan $(17,658)$.

Hasil analisis biaya perawatan dengan keputusan memilih rawat inap pasien rawat inap di UPTD Rumah Sakit Manembo-Nembo Tipe C Bitung, diperoleh data jumlah responden menjawab terjangkau 29 responden (54,7\%) dengan loyal sebanyak 21 responden $(39,6 \%)$ dan kurang loyal sebanyak 8 responden $(15,1 \%)$; sedangkan responden yang menjawab kurang terjangkau 24 responden $(45,3 \%)$ dengan loyal sebanyak 5 responden $(9,4 \%)$ dan kurang loyal sebanyak 19 responden $(35,8 \%)$. Berdasarkan hasil uji analisis chi-square didapatkan hasil dengan nilai $\mathrm{p}=0,000<\mathrm{a}=0,05$ yang menunjukkan terdapat hubungan yang bermakna antara biaya (price) dengan keputusan memilih rawat inap di UPTD Rumah Sakit Manembo-Nembo Tipe C Bitung. Nilai Odd biaya dihitung dengan membandingkan biaya yang kurang terjangkau (numerator) dan terjangkau (denominator) terhadap keputusan untuk tidak memilih rawat inap di RS (kurang loyal). Nilai Odd sebesar 9,975 berarti bahwa responden dengan jawaban biaya yang kurang terjangkau berisiko untuk kurang loyal sebesar 9,975 atau 9 kali lebih besar berisiko untuk tidak memilih dirawat kembali (kurang loyal) dibandingkan dengan responden yang menjawab biaya terjangkau. Nilai kepercayaan diperoleh $(2,779)$ sampai dengan $(35,809)$.

Hubungan personil pemberi perawatan dengan keputusan memilih rawat inap pasien rawat inap di UPTD Rumah Sakit Manembo-Nembo Tipe C Bitung berdasarkan tabulasi silang, diperoleh data jumlah responden menjawab baik 36 responden $(67,9 \%)$ dengan loyal sebanyak 21 responden $(39,6 \%)$ dan kurang loyal sebanyak 15 responden $(25,3 \%)$; sedangkan responden yang menjawab kurang baik 17 responden $(32,1 \%)$ dengan loyal sebanyak 5 responden $(9,4 \%)$ dan kurang loyal sebanyak 12 responden $(22,6 \%)$. Berdasarkan hasil uji analisis chi-square didapatkan hasil dengan nilai $\mathrm{p}=0,000<\mathrm{a}=0,05$ yang menunjukkan terdapat hubungan yang bermakna antara personil (person) dengan keputusan memilih rawat inap di UPTD Rumah Sakit Manembo-Nembo Tipe C Bitung. Nilai Odd personil dihitung dengan membandingkan personil pada kategori kurang baik (numerator) dan baik (denominator) terhadap keputusan untuk tidak memilih rawat inap di RS (kurang loyal). Nilai Odd sebesar 3,360 berarti bahwa responden dengan jawaban personil yang kurang baik berisiko untuk kurang loyal sebesar 3,360 atau 3 kali lebih besar berisiko untuk tidak memilih dirawat kembali (kurang loyal) dibandingkan dengan responden yang menjawab personil yang baik. Nilai kepercayaan diperoleh $(0,976)$ sampai dengan $(11,563)$. 
Analisis promosi terhadap keputusan memilih rawat inap pada pasien rawat inap di UPTD Rumah Sakit Manembo-Nembo Tipe C Bitung, diperoleh data jumlah responden menjawab baik 19 responden $(35,8 \%)$ dengan loyal sebanyak 7 responden $(13,2 \%)$ dan kurang loyal sebanyak 12 responden $(22,6 \%)$; sedangkan responden yang menjawab kurang baik 34 responden $(62,4 \%)$ dengan loyal sebanyak 19 responden $(35,8 \%)$ dan kurang loyal sebanyak 15 responden $(28,3 \%)$. Berdasarkan hasil uji analisis chi-square didapatkan hasil dengan nilai $\mathrm{p}=0,184>\mathrm{a}=0,05$ yang menunjukkan tidak terdapat hubungan yang bermakna antara promosi (promotion) dengan keputusan memilih rawat inap di UPTD Rumah Sakit Manembo-Nembo Tipe C Bitung. Nilai Odd promosi dihitung dengan membandingkan promosi yang kurang baik (numerator) dan baik (denominator) terhadap keputusan untuk tidak memilih rawat inap di RS (kurang loyal). Nilai Odd sebesar 0,461 berarti bahwa promosi RS yang kurang baik berisiko untuk menjadikan pasien kurang loyal sebesar 0,461 kali lebih besar berisiko untuk tidak memilih dirawat kembali (kurang loyal) dibandingkan dengan promosi yang baik. Nilai kepercayaan diperoleh $(0,146)$ sampai dengan $(1,457)$.

Pada kategori fisik terhadap keputusan memilih rawat inap pasien rawat inap di UPTD Rumah Sakit Manembo-Nembo Tipe C Bitung, diperoleh data jumlah responden menjawab baik 40 responden $(75,5 \%)$ dengan loyal sebanyak 18 responden $(34,0 \%)$ dan kurang loyal sebanyak 22 responden (41,5\%); sedangkan responden yang menjawab kurang baik 13 responden $(24,5 \%)$ dengan loyal sebanyak 8 responden $(15,1 \%)$ dan kurang loyal sebanyak 5 responden $(9,4 \%)$. Berdasarkan hasil uji analisis chi-square didapatkan hasil dengan nilai $\mathrm{p}=0,300>\mathrm{a}=0,05$ yang menunjukkan tidak terdapat hubungan yang bermakna antara bukti fisik (physical evidence) dengan keputusan memilih rawat inap di UPTD Rumah Sakit Manembo-Nembo Tipe C Bitung. Nilai Odd bukti fisik dihitung dengan membandingkan bukti fisik yang kurang baik (numerator) dan baik (denominator) terhadap keputusan untuk tidak memilih rawat inap di RS (kurang loyal). Nilai Odd sebesar 0,511 berarti bahwa bukti fisik yang kurang baik berisiko untuk menjadikan pasien kurang loyal sebesar 0,511 kali lebih besar berisiko untuk tidak memilih dirawat kembali (kurang loyal) dibandingkan dengan bukti fisik yang baik. Nilai kepercayaan diperoleh $(0,142)$ sampai dengan $(1,838)$.

Proses layanan terhadap keputusan memilih rawat inap di UPTD Rumah Sakit Manembo-Nembo Tipe C Bitung, diperoleh data jumlah responden menjawab baik 42 responden $(79,2 \%)$ dengan loyal sebanyak 20 responden $(37,7 \%)$ dan kurang loyal sebanyak 22 responden (41,5\%); sedangkan responden yang menjawab kurang baik 11 responden $(20,8 \%)$ dengan loyal sebanyak 6 responden $(11,3 \%)$ dan kurang loyal sebanyak 5 responden $(9,4 \%)$. Berdasarkan hasil uji analisis chi-square didapatkan hasil dengan nilai $\mathrm{p}=0,018<\mathrm{a}=0,05$ yang menunjukkan terdapat hubungan yang bermakna antara proses (process) dengan keputusan memilih rawat inap di UPTD Rumah Sakit Manembo-Nembo Tipe C Bitung. Nilai Odd proses dihitung dengan membandingkan proses yang kurang baik (numerator) dan baik (denominator) terhadap keputusan untuk tidak memilih rawat inap di RS (kurang loyal). Nilai Odd sebesar 0,253 berarti bahwa proses di RS yang kurang baik berisiko untuk menjadikan pasien kurang loyal sebesar 0,253 kali lebih besar berisiko untuk tidak memilih dirawat kembali (kurang loyal) dibandingkan dengan proses yang baik. Nilai kepercayaan diperoleh $(0,080)$ sampai dengan $(0,806)$.

Tabulasi silang yang dilakukan antara produk layanan dengan keputusan memilih rawat inap pasien rawat inap di UPTD Rumah Sakit Manembo-Nembo Tipe C Bitung, diperoleh data jumlah responden menjawab baik 31 responden $(67,2 \%)$ dengan loyal 
sebanyak 21 responden $(39,6 \%)$ dan kurang loyal sebanyak 13 responden $(24,5 \%)$; sedangkan responden yang menjawab kurang baik 19 responden $(35,8 \%)$ dengan loyal sebanyak 5 responden $(9,4 \%)$ dan kurang loyal sebanyak 14 responden $(26,4 \%)$. Berdasarkan hasil uji analisis chi-square didapatkan hasil dengan nilai $\mathrm{p}=0,013<\mathrm{a}=0,05$ yang menunjukkan terdapat hubungan yang bermakna antara produk (product) dengan keputusan memilih rawat inap di UPTD Rumah Sakit Manembo-Nembo Tipe C Bitung. Nilai Odd proses dihitung dengan membandingkan produk pada kategori kurang baik (numerator) dan baik (denominator) terhadap keputusan untuk tidak memilih rawat inap di RS (kurang loyal). Nilai Odd sebesar 4,523 berarti bahwa proses di RS yang kurang baik berisiko untuk menjadikan pasien kurang loyal sebesar 4,523 atau 4 kali lebih besar berisiko untuk tidak memilih dirawat kembali (kurang loyal) dibandingkan dengan produk RS pada kategori baik. Nilai kepercayaan diperoleh $(0,080)$ sampai dengan $(0,806)$.

\section{PENUTUP}

Kesimpulan dari penelitian ini yaitu factor lokasi, biaya, personil, proses dan produk berhubungan dengan keputusan memilih rawat inap. faktor yang paling dominan yang berhubungan dengan keputusan memilih rawat inap adalah biaya.

\section{REFERENSI}

Adiekoesoemo. S. 2012. Manajemen Rumah Sakit. Jakarta: Pustaka Sinar Harapan. Aditama. T. Y. 2015. Manajemen Administrasi Rumah Sakit. Jakarta: UI-Press. Anonim. 2018. Profil UPTD Rumah Sakit Manembo-Nembo Tipe C Bitung. Bitung Anshori, Nurani Siti. 2013. Makna Kerja (Meaning of Work) Suatu Studi Etnografi Abdi Dalem Keraton Ngayogyakarta Hadiningrat Daerah Istimewa Yogyakarta. Jurnal Psikologi Industri dan Organisasi Vol. 2, No. 3, Desember 2013

Atira. 2019. Pengaruh Jenis Kelamin, Usia, Tingkatan Pendidikan dan Tingkatan Pendapatan terhadap Loyalitas Nasabah dengan Kepuasan Nasabah sebagai variabel Intervening (Studi Kasus Pada Pengguna Bank Syariah di Kota Yogyakarta. Karya Tulis Ilmiah, Program Studi Perbankan Universitas Islam Negeri Sunan Kali Jaga Yogyakarta.

Azam. M. 2007. Sistem informasi admisi pasien rawat inap Untuk membantu pengambilan keputusan klinis Dan administrasi di badan rumah Sakit umum daerah (RSUD) dr. H. Soewondo Kabupaten Kendal. Semarang: Program Pasca Sarjana Universitas Diponegoro.

Azwar. A. 2010. Pengantar Administrasi Kesehatan. Jakarta: Binarupa Aksara Publisher. Dumpapa. Yella. 2010. Hubungan Lokasi, Biaya, Personil dan Informasi rumah sakit dengan keputusan memilih rawat inap di RSUD Bitung. Manado: Program Pasca Sarjana Universitas Sam Ratulangi.

Hartono. B. 2010. Manajemen Pemasaran untuk Rumah Sakit. Jakarta: PT Rineka Cipta.

Hastuti, S.K.W. 2017. Hubungan Mutu Pelayanan dengan Kepuasan Pasien Peserta BPJS di Rumah Sakit Umum Daerah Yogyakarta. Kes Mas: Jurnal Fakultas Kesehatan Masyarakat Volume 11, Issue 2, September 2017, pp. 161 168 ISSN: $1978-0575$

Herlambang. S. 2016. Manajemen Pelayanan Kesehatan Rumah Sakit. Yogyakarta: Gosyen Publishing.

Kotler. P. 2012. Marketing Management. $14^{\text {th }}$ Edition. New Jersey: Prentice-Hall.

Kotler. P. 2014. Marketing Management. New Jersey: Prentice-Hall. 
Maria, U. 2013. Pengaruh Bauran Pemasaran Marketing Mix terhadap Keputusan Menggunakan Jasa Rawat Jalan di Rumah Sakit Bina Sehat Jember. Jurnal Aplikasi Manajemen. Vol.11, No.3, 2013

Muninjaya. A.A.Gde. 2004. Manajemen Kesehatan. Jakarta: Kedokteran EGC.

Napirah, M. 2016. Faktor-Faktor Yang Berhubungan Dengan Pemanfaatan Pelayanan Kesehatan Di Wilayah Kerja Puskesmas Tambarana Kecamatan Poso Pesisir Utara Kabupaten Poso. Jurnal Pengembangan Kota (2016) Volume 4 No. 1 (29-39)

Ngai Eric W.T., Heung Vincent C.S., Wong Y.H dan Chan K.y. 2007. Consumer Complaint Behavior of Asians and Non Asian About Hotel Services. European Journal of Marketing.

Nisa, I. 2017. Hubungan Bauran Pemasaran Terhadap Keputusan Pasien Memilih Unit Rawat Jalan di Rumah Sakit Universitas Ahmad Dahlan Yogyakarta. Fakultas Kesehatan Masyarakat Universitas Ahmad Dahlan

Notoadmojo. S. 2010. Promosi Kesehatan Teori dan Aplikasi. Jakarta: Rineka Cipta.

Notoatmodjo. S. 2007. Kesehatan Masyarakat: Ilmu dan seni. Jakarta: PT Rineka Cipta.

Rawung. E. 2013. Hubungan Antara Persepsi Pasien Umum Tentang Bauran Pemasaran Jasa Dengan Loyalitas Pasien Di Unit Rawat Jalan Rumah Sakit Jiwa Prof. dr. V. I. Ratumbuysang Provinsi Sulawesi Utara. Manado: Program Pascasarjana Universitas Sam Ratulangi Manado.

Rengkuan, S. R. 2014. Hubungan Antara Persepsi Pasien Umum tentang Bauran Pemasaran Jasa dengan Loyalitas Pasien Rawat Jalan RS Advent Manado. Manado: Program Pascasarjana Universitas Sam Ratulangi Manado.

Retnanigtyas, DKK. 2016. Persepsi Pasien terhadap Bauran Pemasaran Rumah Sakit dan Pilihan Rumah Sakit. Malang: Program Studi Magister Manajemen Rumah Sakit Universitas Brawijaya Malang.

Rinaldi. E. A. 2018. Analisis Hubungan Bauran Pemasaran Terhadap Loyalitas Pasien.

Riset Kesehatan Dasar (RISKESDAS) Tahun 2013.

Riswadani, Y.T.S. 2013. Pengaruh Fasilitas, Biaya dan Promosi terhadap Kepuasan Pasien Rawat Inap. Jurnal Ekonomi Manajemen Sumber DayaVol. 14, No. 2, Desember 2013

Rowland and Rowland. 2015. Hospital Administration Handbook.

Sabarguna. B. S. 2014. Sistem Informasi Pemasaran Rumah Sakit Berbasis Rekam Medis (SIPRS-B-RM). Yogyakarta: UGM Press.

Sabran dkk, 2014. Evaluasi Bauran Pemasaran di rumah sakit Universitas Hasanudin.

Saragih. M dkk, 2017. Faktor-faktor bauran pemasaran yang berhubungan dengan kepuasan pasien.

Sarbana, G.R. 2015. Hubungan Antara Biaya dan Lokasi dengan Keputusan Pasien Untuk Kembali Memilih Rawat Inap di RSU Pancaran Kasih GMIM Manado. Fakultas Kesehatan Masyarakat Universitas Sam Ratulangi

Savitri, D.N. 2013. Pengaruh Kualitas Pelayanan, Lokasi, Dan Tarif Terhadap Kepuasan Pasien Rawat Inap Rumah Sakit Lestari Raharja Kota Magelang (Studi Kasus Pada Pasien Rawat Inap Non Asuransi) Universitas Diponegoro, difasavitri19@gmail.com

Trisnantoro. L. 2015. Memahami Penggunaan Ilmu Ekonomi Dalam Manajemen Rumah Sakit. Yogyakarta: UGM Press. 
Tumiwa. A, 2016. Hubungan Antara Bauran Pemasaran dan Pekerjaan Dengan Keputusan Memilih Rawat Inap di Rumah Sakit Umum Pancaran Kasih GMIM Manado.

Undang-undang Republik Indonesia Nomor 44 Tahun 2009 tentang Rumah Sakit.

Wardani, B.M. 2013. Pengaruh Kualitas Pelayanan Terhadap Kepuasan Pelanggan Dari Sudut Pandang Pasien Dan Pendamping Pasien (Studi Kasus Di Rs Medistra, Jakarta). Jurnal Manajemen [vol 1 no. 1 mei 2013: 1-12]

Wulandari, F.K. 2016. Analisis Karakteristik dan Persepsi Pengguna Pelayanan Terhadap Pemanfaatan Puskesmas Sebagai Gatekeeper di Dua Puskesmas Kota Bekasi Tahun 2016. Program Studi Magister Ilmu Kesehatan Masyarakat Fakultas Kesehatan Masyarakat Universitas Indonesia, Depoke-mail: fitzghasani@gmail.com 